\title{
Taxonomic status of Ascocotyle (Phagicola) rara Arruda, Muniz-Pereira et Pinto, 2002 (Digenea: Heterophyidae)
}

\author{
Tomáš Scholz ${ }^{1}$, Luís C. Muniz-Pereira ${ }^{2}$ and Cláudia Portes Santos ${ }^{3}$ \\ ${ }^{1}$ Institute of Parasitology, Biology Centre, Academy of Sciences of the Czech Republic, Branišovská 31, 37005 České \\ Budějovice, Czech Republic; \\ ${ }^{2}$ Laboratório de Helmintos Parasitos de Vertebrados, Departamento de Helmintologia, Instituto Oswaldo Cruz, FIOCRUZ, Av. \\ Brasil 4365, Rio de Janeiro, 21040-900, Brazil; \\ ${ }^{3}$ Laboratório de Avaliação e Promoção da Saúde Ambiental, Departamento de Biologia, Instituto Oswaldo Cruz, FIOCRUZ, Av. \\ Brasil 4365, Rio de Janeiro, 21040-900, Brazil
}

Key words: Trematoda, Heterophyidae, systematics, fish-eating birds, Brazil

\begin{abstract}
Holotype and paratype of Ascocotyle (Phagicola) rara Arruda, Muniz-Pereira et Pinto, 2002, a heterophyid trematode recently described on the basis of two worms collected by Lauro Travassos in 1921 in the intestine of Ixobrychus exilis (Gmelin) from Brazil, were studied. The morphology of the worms revealed their conspecificity with Ascocotyle (Phagicola) angeloi Travassos, 1928 found in the same host. Both the taxa have a similar length (between 600 and $900 \mu \mathrm{m}$ ) and shape of the body (long pyriform), the long intestinal caeca reaching to the ovarian level, a long posterior muscular prolongation of the oral sucker and the prepharynx, transverse uterine loops situated between the ventral sucker and testes, and the gonotyl with more than 20 digitiform pockets. Consequently, A. (P.) rara is proposed as a junior synonym of Ascocotyle (Phagicola) angeloi.
\end{abstract}

In 1921, the Brazilian helminthologist Lauro Travassos collected numerous heterophyid trematodes belonging to the genus Ascocotyle Looss, 1899 from the intestine of the least-bittern, Ixobrychus exilis (Gmelin) [syn. Ardetta erythromelas (Vieill.)] from Rio de Janeiro, Brazil. Based on this sample, Travassos described in 1928 the species Ascocotyle (Ascocotyle) felippei, A. (Phagicola) angeloi and $A$. (P.) pindoramensis. However, most of these specimens were grouped on permanent slides, altogether with the host's intestinal scrapings and, although the labels refer to their status as type or voucher specimens, they were not separately assigned on the slides deposited at the Helminthological Collection of Instituto Oswaldo Cruz (CHIOC).

Arruda et al. (2002), while studying Travassos' material of Ascocotyle from CHIOC, found two specimens on the slides Nos. 2632 and 2639 without circumoral spines, which they described as Ascocotyle (Phagicola) rara. Re-examination of both specimens has revealed new morphological data which justify a revision of the taxonomic status of the species.

\section{MATERIALS AND METHODS}

The holotype of $A$. (P.) rara [CHIOC 2632 - mounted together with several specimens of Ascocotyle (Phagicola) angrense Travassos, 1916 and 3 specimens of $A$. (P.) pindoramensis (Travassos, 1928)] and its paratype [CHIOC 2639 - together with specimens of A. (P.) pindoramensis and Ascocotyle (Phagicola) diminuta (Stunkard et Haviland, 1924)] were studied. In addition, the holotype and vouchers of Ascocotyle (Phagicola) angeloi Travassos, 1928 (CHIOC 2630) were also examined (Figs. 1, 3, 5, 6).

\section{RESULTS}

Ascocotyle (Phagicola) rara Arruda, Muniz-Pereira et Pinto, 2002

Figs. 2, 4, 7

Adult (measurements provided in Table 1 are based on CHIOC 2632): Body elongate, long pyriform, with maximum width at ovarian level. Tegument partially spinose. Remnants of eyespot pigments scattered at prepharyngeal level. Oral sucker subterminal, with a long, muscular prolongation dorsal to prepharynx. Ventral sucker post-equatorial. Prepharynx long; pharynx muscular, oval; oesophagus variable in length. Intestinal caeca long, reach ovarian level. Testes symmetrical, transversely oval, close to posterior end of body. Seminal vesicle not visible. Ventrogenital sac with slit-like aperture, antero-sinistral to ventral sucker, contains muscular oval gonotyl with more than 20 pockets (refractile bodies) disposed in a horizontal row. Ovary round to oval, anterior to right testis. Seminal receptacle voluminous, slightly posterior to ovary. Vitellaria form 2 lateral bands of 7 follicles between ovary and posterior level of testes. Uterus inter- and extracaecal, between testes and anterior border of ventral sucker. Eggs numerous, operculate. Excretory vesicle not seen. Excretory pore dorsal, slightly subterminal. 

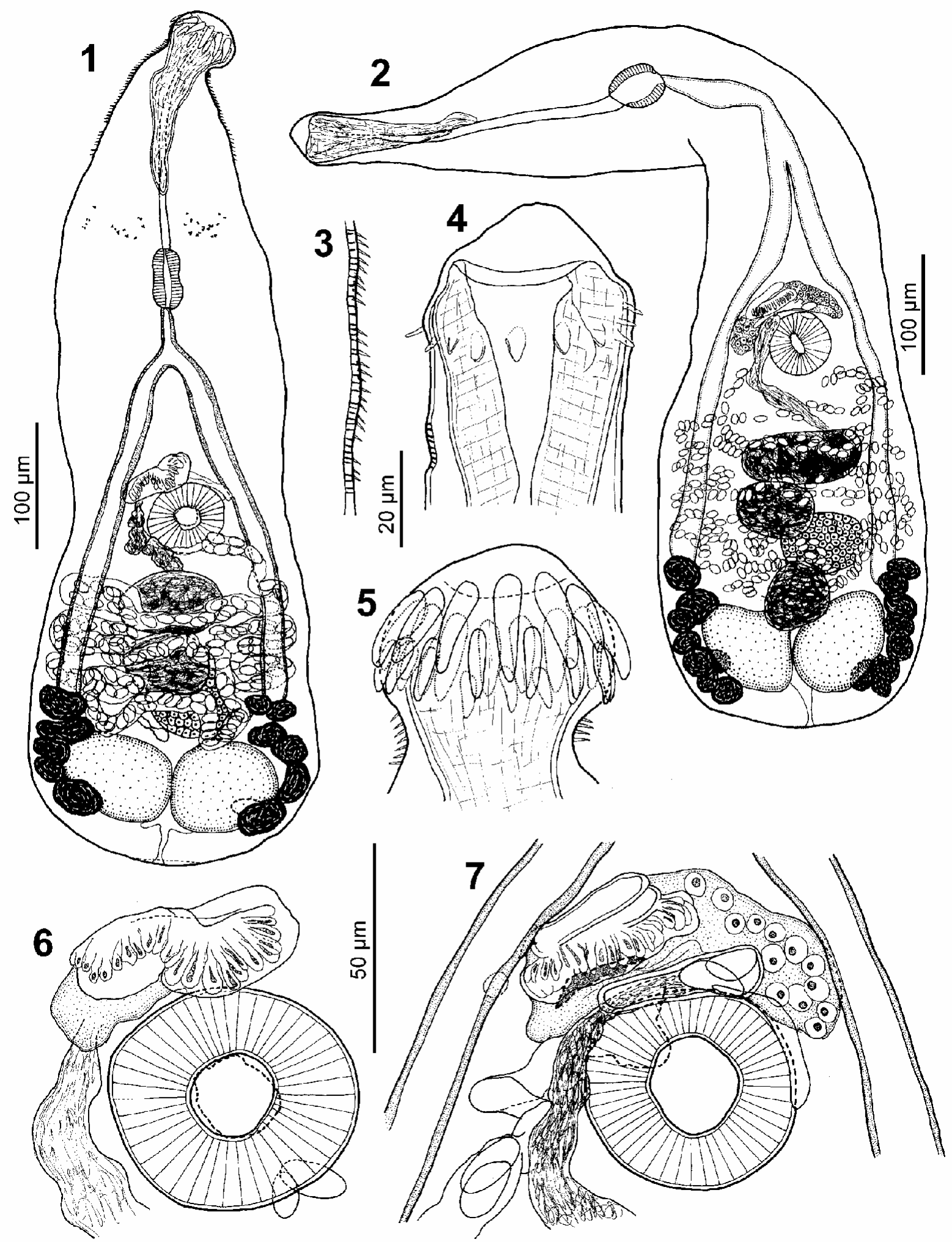

Figs. 1, 3, 5, 6. Ascocotyle (Phagicola) angeloi, holotype (CHIOC 2630). Figs. 2, 4, 7. Ascocotyle (Phagicola) rara, holotype (CHIOC 2632). Fig. 1. Total view, dorsal. Fig. 2. Total view, anterior end ventral, posterior end dorsal. Fig. 3. Tegumental spines. Figs. 4, 5. Anterior end. Figs. 6, 7. Terminal genitalia, dorsally; note the gonotyl with digitiform pockets. Scale bars: Figs. $1,2=100 \mu \mathrm{m}$; Figs. $3-5$ (same scale bar) $=20 \mu \mathrm{m}$; Figs. 6,7 (same scale bar) $=50 \mu \mathrm{m}$. 
Table 1. Comparative measurements (in $\mu \mathrm{m}$ ) of Ascocotyle (Phagicola) rara and A. (P.) angeloi.

\begin{tabular}{|c|c|c|c|}
\hline Species & \multicolumn{2}{|c|}{ A. (P.) rara } & A. (P.) angeloi \\
\hline Character/Authority & Arruda et al. 2002 & Present study & Ostrowski de Núñez 1998 \\
\hline Body length & $630-802$ & 864 & 592-992 (697)* \\
\hline Body width & $201-216$ & 224 & $192-240(206)$ \\
\hline Oral sucker (width) & $36-46$ & 40 & $38-47(44)$ \\
\hline Ventral sucker & $54 \times 57$ & $56 \times 59$ & $50-63(55) \times 41-60(53)$ \\
\hline Oral appendage & $126-129$ & 130 & $73-221(130)$ \\
\hline Prepharynx & $205-226$ & 211 & \\
\hline Pharynx & $39-43 \times 36$ & $36 \times 37$ & $38-50(45) \times 25-38(34)$ \\
\hline Oesophagus & 108 & 190 & $28-142(67)$ \\
\hline Testes & $\begin{array}{c}46-54 \times 75 \\
43-54 \times 72-75\end{array}$ & $\begin{array}{l}69 \times 82 \\
64 \times 90\end{array}$ & $41-69(55) \times 57-91(75)$ \\
\hline Genital sac & $21 \times 31-50$ & $29 \times 73$ & $28-35(32) \times 50-69(56)$ \\
\hline No. pockets of gonotyl & 16 & $>20$ & 29 \\
\hline Ovary & $50-54 \times 61-72$ & $50 \times 62$ & $44-60(48) \times 54-85(66)$ \\
\hline Eggs & $18 \times 10$ & $17 \times 10$ & $15.5-21(18) \times 8-11(9.5)$ \\
\hline
\end{tabular}

*Range with mean in parentheses

\section{DISCUSSION}

Re-examination of Ascocotyle (Phagicola) rara specimens has shown other morphological features than those in the original description by Arruda et al. (2002) and slight differences in some of the measurements (Table 1).

The holotype and paratype of $A$. (P.) rara are in fact smooth, lacking any tegumental spines that were reported and illustrated by Arruda et al. (2002). Actually, the outer, syncytial layer of the tegument of $A$. $(P$.) rara is absent, apparently having disappeared together with tegumental spines after the death of the worms (Figs. 2, 4). The basal layer of the tegument contains transverse muscle fibres, which are markedly stained, thus giving the impression of spination of the tegument (Fig. 4). If correctly focused, these fibres can be seen to form transverse striation around the body of the worms. True tegumental spines of Ascocotyle species are in fact markedly larger than these muscle fibres. For example, tegumental spines of the holotype of Ascocotyle (P.) angeloi (CHIOC 2630) can be easily recognized and distinguished from these muscle fibres by their larger size, conical shape and direction (slightly backwards) (Fig. 3).

Arruda et al. (2002) were correct in reporting the circumoral spines to be absent. However, they overlooked that the spines had been lost secondarily after the worms' death, as seen from the presence of small, auricular projections of the muscular (basal) layer of the tegument encircling the anterior extremity (Fig. 4). These projections are arranged regularly and apparently indicate the sites where circumoral spines (probably their base) were inserted in living worms. They also look similar to the pockets that hold the sharp tips of the spines in the cryptogonimid Stemmatostoma pearsoni described and illustrated by scanning electron microscopy by Cribb (1987).
The projections are best visible on the lateral sides of the anterior extremity as narrow, spine-like, posteriorly directed processes. Their position and distribution, especially on the lateral sides of the body, indicate that there may have been two complete circles of circumoral spines. Although the complete spination pattern cannot be assessed only on the basis of these projections, the number of spines can be roughly estimated to have been about 6-8 (most probably 7) on one side, thus giving an estimation of the total number of about 12-16 (most probably 14) spines in one circle, i.e. 24-32 (probably 28) spines in total, considering the alleged presence of two complete circles.

Arruda et al. (2002) presented the specimen illustrated in Fig. 1 as in total, ventral view, but in the slide itself, the specimen is folded at the mid-length, showing the anterior half part in the ventral view and the posterior part of the body in the dorsal view. Considering this, the posterior appendage of the oral sucker is in fact dorsal to the prepharynx and the genital sac is anterosinistral to ventral sucker, differing from the original description.

In neither of the two specimens of $A$. (P.) rara does the genital pore open dextral to the genital sac as described by Arruda et al. (2002). In the present study, the terminal part of the uterus was observed to simply follow the antero-sinistral margin of the ventral sucker to open into the ventrogenital sac together with the ejaculatory duct and gonotyl (Fig. 7). In general, the arrangement of the terminal genitalia of $A$. $(P$.) rara corresponds to that typical of other species of Ascocotyle (see, e.g., Font et al. 1984a,b, Ostrowski de Núñez 1993, 1998, Scholz et al. 1997a,b, 2001, Scholz 1999).

The gonotyl of $A$. (P.) rara is muscular, slightly inclined (oblique), situated between the sinistral intestinal caecum and ventral sucker. The posterior part of the 
gonotyl contains numerous digitiform pockets (refractile bodies). Their precise number is difficult to count because they overlap each other, especially those on the lateral sides of the gonotyl. However, more than 20 pockets are present in the holotype (CHIOC 2632 - Fig. 7). This contrasts with the observation of Arruda et al. (2002), who reported only 16 pockets.

The eggs of $A$. (P.) rara were described as unoperculate although they possess, in fact, a fine but distinct operculum, which is difficult to observe in most eggs. This corresponds with the situation in the whole family, which is characterized by possessing operculate eggs (Pearson 2007).

Ascocotyle (P.) rara was primarily compared to the two most similar taxa, namely Ascocotyle (Phagicola) mollienisicola (Sogandares-Bernal et Bridgman, 1960) [recently synonymized with Ascocotyle (Phagicola) pindoramensis Travassos, 1928 by Simões et al. 2006] and $A$. (P.) angeloi. Apart from the absence of spines, Arruda et al. (2002) differentiated Ascocotyle (P.) mollienisicola $[=A$. $(P$.) pindoramensis $]$ and $A$. (P.) rara by its gonotyl being reported by Sogandares-Bernal and Bridgman (1960) to perforate the uterine loops ("... uterus appears to perforate the gonotyl") in the former species [versus the uterus being reported by Arruda et al. 2000 to open outside of the genital sac in $A$. $(P$.) rara]. Besides the most probable presence of circumoral spines in $A$. (P.) rara, both species differ markedly in several features, such as the pyriform body of $A$. $(P$.) pindoramensis, which is much smaller than $A$. $(P$.) rara (228-313 $\mu \mathrm{m}$ versus $630-802 \mu \mathrm{m})$, possesses a very short posterior prolongation of the oral sucker, the intestinal caeca curved medially in their terminal part, different course of uterine loops, distinct distribution of vitelline follicles [follicles form one longitudinal band in $A$. $(P$.$) rara whereas they are grouped more irregularly in$ $A$. (P.) pindoramensis] and a lower number of digitiform pockets of the gonotyl in $A$. (P.) pindoramensis [13-16 versus more than 20 in $A$. (P.) rara] (Simões et al. 2006; present study).

Ascocotyle (P.) rara corresponds in its morphology and measurements in all but one characteristic to Asco- cotyle (Phagicola) angeloi (Figs. 1-7, Table 1). Both taxa are identical in possessing an elongate, relatively large body, long posterior muscular appendage, prepharynx and oesophagus, very long intestinal caeca reaching posterior to the ovarian level, a few vitelline follicles clustered along the lateral sides of the body between the ovary and posterior extremity, and transverse uterine loops situated between the ventral sucker and testes. The only difference between $A$. (P.) rara and $A$. (P.) angeloi was in the absence/presence of circumoral spines. However, the present study has shown that the spines were most probably present in live $A$. $(P$.) rara worms and have been lost after the worms' death. The number and distribution of auricular projections on the anterior extremity of $A$. $(P$.) rara indicate that their number may have been identical to that typical of A. (P.) angeloi, i.e. $14+14=28$ (Ostrowski de Núñez 1998).

Taking into account the differences from the original description of $A$. (P.) rara, namely (i) both specimens (holotype and paratype) have lost the external layer of the tegumental spines, (ii) circumoral spines were almost certainly present, (iii) the distal course of the uterus and the position of the genital pore correspond to the general pattern found in other species of Ascocotyle, (iv) the gonotyl has in fact more than 20 digitiform pockets and (v) eggs are operculate, and on the basis of the morphological similarity between $A$. (P.) rara and $A$. (P.) angeloi, found in the same host, $A$. (P.) rara is now considered a junior synonym of $A$. $(P$.) angeloi.

Acknowledgements. Thanks are due to Dr. Dely Noronha, Curator of the Helminthological Collection of the Instituto Oswaldo Cruz (CHIOC), Rio de Janeiro, Brazil, for enabling the authors to study Ascocotyle specimens collected by Lauro Travassos. The present study and stay of the senior author in Brazil in 2005 were supported by the Grant Agency of the Academy of Sciences of the Czech Republic (project no. A6022404), the Institute of Parasitology, AS CR (project no. Z60220518) and the Research Centre "Ichthyoparasitology" (LC 522).

\section{REFERENCES}

ARRUDA V.S., MUNIZ-PEREIRA L.C., PINTO R.M. 2002: Ascocotyle (Phagicola) rara sp. n. (Digenea, Heterophyidae) from Ixobrychus exilis (Aves, Ardeidae) in Brazil. Rev. Bras. Zool. 19: 145-149.

CRIBB T. 1987: The life-cycle and morphology of Stemmatostoma pearsoni, gen. et sp. nov., with notes on the morphology of Telogaster opisthorchis Macfarlane (Digenea, Cryptogonimidae). Aust. J. Zool. 34: 279-304.

FONT W.F., HEARD R.W., OVERSTREET R.M. 1984a: Life cycle of Ascocotyle gemina $\mathrm{n}$. sp., a sibling species of A. sexidigita (Digenea: Heterophyidae). Trans. Am. Microsc. Soc. 103: 392-407.
FONT W.F., OVERSTREET R.M., HEARD R.W. 1984b: Taxonomy and biology of Phagicola nana (Digenea: Heterophyidae). Trans. Am. Microsc. Soc. 103: 408-422.

OSTROWSKI de NÚÑEZ M. 1993: Life-history studies of heterophyid trematodes in the Neotropical Region: Ascocotyle (Phagicola) diminuta (Stunkard \& Haviland, 1924) and $A$. (P.) angrense Travassos, 1916. Syst. Parasitol. 24: 191-199.

OSTROWSKI de NÚÑEZ M. 1998: Life cycle of Ascocotyle (Phagicola) angeloi (Digenea: Heterophyidae) in the Neotropical region. Folia Parasitol. 45: 199-204. 
PEARSON J.C. 2007: Heterophyidae Leiper, 1909. In R.A. Bray, A. Jones and D.I. Gibson (Eds.), Keys to the Trematoda, Vol. 3. CAB International, Wallingford \& The Natural History Museum, London. (In press.)

SCHOLZ T. 1999: Taxonomic study of Phagicola longa (Ransom, 1920) (Digenea: Heterophyidae) and related taxa. Syst. Parasitol. 43: 147-158.

SCHOLZ T., AGUIRRE-MACEDO M.L., SALGADO-MALDONADO G. 2001: Trematodes of the family Heterophyidae (Digenea) in Mexico: a review of species and new host and geographical records. J. Nat. Hist. 35: 17331772.

SCHOLZ T., VARGAS-VÁZQUEZ J., AGUIRRE-MACEDO M.L., VIDAL-MARTÍNEZ V.M. 1997a: Species of Ascocotyle Looss, 1899 (Digenea: Heterophyidae) from the Yucatan Peninsula, Mexico. Syst. Parasitol. 36: 161-181.

Received 30 June 2006
SCHOLZ T., VARGAS-VÁZQUEZ J., VIDAL-MARTÍNEZ V.M., AGUIRRE-MACEDO L. 1997b: Ascocotyle nunezae n. sp. (Digenea: Heterophyidae) from Yucatan, Mexico. J. Parasitol. 83: 141-147.

SIMÕES S.B.E., SCHOLZ T., BARBOSA H.S., SANTOS C.P. 2006: Taxonomic status, redescription, and surface ultrastructure of Ascocotyle (Phagicola) pindoramensis $\mathrm{n}$. comb. (Digenea: Heterophyidae). J. Parasitol. 92: 501508.

SOGANDARES-BERNAL F., BRIDGMAN J.F. 1960: Three Ascocotyle komplex trematodes (Heterophyidae) encysted in fishes from Louisiana including the description of a new genus. Tulane Stud. Zool. 8: 31-39.

TRAVASSOS L. 1928: Deux nouvelles espèces du genre Ascocotyle Looss, 1899. C. R. Soc. Biol. Paris 100: 939940.

Accepted 12 September 2006 